\title{
Evaluation of Perceived Stress Levels of Radiology Workers Regarding COVID-19 Outbreak
}

\section{Radyoloji Çalışanlarının COViD-19 Salgınıyla ilgili Algılanan Stres Düzeylerinin Değerlendirilmesi}

(iD Hatice Nilden ARSLAN1', id Ayşegül İdil SOYLU²

'Ondokuz Mayıs University Faculty of Medicine, Department of Public Health, Samsun, Turkey

2Ondokuz Mayıs University Faculty of Medicine, Department of Radiology, Samsun, Turkey

\section{ABSTRACT}

Objective: The purpose of this study is to investigate the perceived stress levels of radiology workers and associated factors during the Coronavirus disease-19 (COVID-19) outbreak.

Methods: A descriptive questionnaire prepared by the researchers was completed online by employees who work in the radiology department of various health institutions in Turkey. In our study, the perceived stress scale was used. The necessary ethics approval was obtained for the study. SPSS Statistics for Windows, Version 22.0 (Armonk, NY: IBM Corp) was used for statistical analysis of the data. Results: The average age of 573 radiology workers participating in the study was $34.0 \pm 9.3$ years and $50.1 \%$ were women. The scores received by radiology workers from the perceived stress scale were 27.8 \pm 6.4 (median: 27.0, minimum-maximum: 6-50). In our study, it was determined that the perceived stress score was statistically significantly higher $(\mathrm{p}<0.05)$ in women and in those who lived with individuals over the age of 60 , those working as radiology technicians, those who had a chronic disease, those who increased smoking, those who used social media more often than before, those who had not received training on COVID-19 infection, those who thought that the measures taken against COVID-19 infection were insufficient, and those who had contact with a patient with COVID-19.

Conclusion: In our study, we identified the perceived high stressrelated factors that we thought could be useful for psychological support during the COVID-19 outbreak. With early detection of radiology workers at risk, we believe that both the mental health of the employees can be protected and workload loss can be prevented. Keywords: COVID-19, pandemic, perceived stress score, radiology workers

\section{ÖZ}

Amaç: Bu çalışmanın amacı koronavirüs hastalı̆ı̆-19 (COVID-19) salgını sırasında radyoloji çalışanlarının algılanan stres düzeylerini ve bununla ilişkili faktörleri incelemektir.

Yöntemler: 15 Nisan-18 Nisan 2020 tarihleri arasında araştırmacılar tarafından hazırlanan tanımlayıcı tipte anket Türkiye'deki çeşitli sağlık kuruluşlarının radyoloji departmanlarında görev yapan radyoloji çalışanları tarafından online dolduruldu. Çalışmamızda algılanan stres ölçeği (perceived stress scala) kullanıldı. Çalışma için gerekli etik izin alındı. Verilerin istatistiksel analizlerinde SPSS 22.0 paket programı kullanıldı.

Bulgular: Çalışmaya katılan 573 radyoloji çalışanının yaş ortalaması $34,0 \pm 9,3$ yıl olup, $\% 50,1$ 'i kadındı. Radyoloji çalışanlarının algılanan stres ölçeğinden aldıkları puan 27,8 6,4 (median: 27,0, minimummaksimum: 6-50) idi. Çalışmamızda kadınların, 60 yaş üstü bireylerle birlikte yaşayanların, radyoloji teknisyeni/teknikeri olarak çalışanların, kronik bir hastalığa sahip olanların, sigara kullanımı artanların, sosyal medyayı eskisinden daha sı kullananların, COVID-19'lu hastayla teması olanların, COVID-19 enfeksiyonu ile ilgili bir eğitim almayanların ve COVID-19 enfeksiyonuna karşı alınan önlemlerin yetersiz olduğunu düşünenlerin algıladıkları stresin istatistiksel olarak anlamlı düzeyde daha yüksek olduğu belirlendi $(\mathrm{p}<0,05)$.

Sonuç: Çalışmamızda, COVID-19 salgını sırasında psikolojik destek için kullanılabileceğini düşündüğümüz algılanan yüksek stres ile ilişkili faktörleri tanımladık. Risk altındaki radyoloji çalışanlarının erken tespit edilmesiyle hem çalışanların ruh sağlığının korunabileceğini hem de iş yükü kaybının önlenebileceğini düşünüyoruz. Bununla birlikte risk gruplarına yönelik yapılacak etkili müdahaleler için daha kapsamlı çalışmalara ihtiyaç vardır.

Anahtar Sözcükler: COVID-19, salgın, algılanan stres ölçeği, radyoloji çalışanları
*This work was supported by Gilead Sciences.

Address for Correspondence: Hatice Nilden ARSLAN, Ondokuz Mayıs University Faculty of Medicine, Department of Public Health, Samsun, Turkey

E-mail: haticenilden.arslan@omu.edu.tr ORCID ID: orcid.org/0000-0002-3237-7123

Cite this article as: Arslan HN, Soylu Ai. Evaluation of Perceived Stress Levels of Radiology Workers Regarding COVID-19 Outbreak. Bezmialem Science 2021;9(Supplement 1):25-31.

${ }^{0}$ Copyright 2021 by the Bezmiâlem Vakıf University

Bezmiâlem Science published by Galenos Publishing House.
Received: 15.06 .2020

Accepted: 01.07.2020 


\section{Introduction}

In December 2019, a new outbreak of pneumonia occurred in Wuhan City, Hubei province of China, of unknown etiology. This disease, which was determined to be caused by a new coronavirus, was named Coronavirus disease-19 (COVID-19) by the World Health Organization $(1,2)$. The virus, which is known as severe acute respiratory syndrome (SARS)-CoV-2 leads to an acute respiratory infection that spreads via droplets, respiratory secretions, and direct contact $(3,4)$. Transmission during health care also plays an important role in the spread of the disease (5).

The reverse transcriptase-polymerase chain reaction test (RTPCR) is the gold standard in the diagnosis of COVID-19. However, the changes in the incubation period of the disease, low patient viral load, or variable positivity rates of the tests caused by disruptions in taking the test sample have increased the importance of radiological findings in diagnosis. In their research comparing the sensitivity of thorax computed tomography (CT) and RT-PCR, Fang et al. (6) reported that RT-PCR sensitivity was $71 \%$ for COVID-19 infection, whereas CT sensitivity was $98 \%(\mathrm{p}<0.001)$. The study supported the use of thorax CT for COVID-19 screening, especially in patients with a negative RT-PCR test where clinical and epidemiological features are compatible with COVID-19 infection (6,7). Radiology personnel are at risk for COVID-19 infection due to increased CT examinations because of the increased importance of imaging methods in diagnosis (8).

Outbreaks are known to cause problems such as anxiety, depression, and post-traumatic stress disorder $(9,10)$. In the studies conducted during the SARS epidemic, it was observed that especially healthcare workers were adversely affected due to the risk of infection and increased workload, and they had anxiety over the possibility of infecting their relatives (11-13). Factors such as the increasing number of cases and lack of personal protection and medications cause a psychological burden on healthcare workers due to the pandemic $(14,15)$. The aim of this study is to investigate the perceived stress levels of radiology workers and related factors during the COVID-19 outbreak.

\section{Method}

The universe of this descriptive study constitutes radiologists and radiology technicians working in the radiology department at various health institutions in Turkey. The data were collected on social media (WhatsAPP, Twitter, Linkedin) using the online questionnaire prepared by the researchers. An information note explaining the purpose of the research was added to the questionnaire form, and a check box was added to the questionnaire that they cannot continue without giving consent that they voluntarily participated in the study. Necessary ethical permission was obtained for the study. The perceived stress scale (PSS) and questions about sociodemographic features were used in the questionnaire.

The PSS was developed by Cohen, Kamarck, and Mermelstein, and was adapted to Turkish by Eskin et al. $(16,17)$. Consisting of 14 items in total, the PSS is designed to measure how stressful some situations in a person's life are perceived to be. The participants evaluate each item on a 5-point Likert scale ranging from "Never (0)" to "Very often (4)." A high score indicates the excessive perception of stress by the person.

\section{Statistic Analysis}

SPSS Statistics for Windows, Version 22.0 (Armonk, NY: IBM Corp) was used for statistical analysis of the data. The Kolmogorov-Smirnov test was used to evaluate the conformity of the quantitative data to the normal distribution. On this basis, nonparametric tests were chosen. In pair group comparisons, a Mann-Whitney $U$ test was used. For comparisons of more than two groups, first a Kruskal-Wallis Test and then a BonferroniCorrected Mann-Whitney $U$ test were used. Values of $\mathrm{p}<0.05$ were considered statistically significant for all tests.

\section{Results}

The average age of 573 radiology workers participating in the study was $34.0 \pm 9.3$ years and $50.1 \%$ were women. In all, $59 \%$ of the participants were married and $51.8 \%$ had at least one child. The frequency of those living with individuals over the age of 60 was $15.4 \%$. A total of $82.0 \%$ of the participants worked in pandemic hospitals, $18.0 \%$ in other health institutions (Integrated hospital, Branch hospital, Cancer early diagnosis and training center, Tuberculosis dispensary, etc.). Average working time was $10.72 \pm 8.6$ years, $19.7 \%$ were radiologists, and $80.3 \%$ were radiology technicians. The distribution of the participants according to some sociodemographic characteristics is shown in Table 1.

While $79.9 \%$ of radiology workers did not have any known chronic diseases, there was hypertension in $3.7 \%$, COPD or asthma in $3.8 \%$, diabetes in $1.7 \%$, immunosuppressive disease in $1.9 \%$ and other diseases (mental illness, musculoskeletal system diseases, peptic ulcer etc.) in $9.2 \%$. In all, $90.8 \%$ of participants stated that they did not have any mental illnesses diagnosed previously, while $3.0 \%$ had a previous mental illness, $3.7 \%$ had an ongoing mental illness, and $2.4 \%$ started to experience mental problems after the COVID-19 outbreak.

A total of $62.0 \%$ of the participants did not smoke cigarettes, and $80.6 \%$ did not use alcohol. When participants were asked about changes in these habits since the COVID-19 outbreak; $41.7 \%$ of smokers had not made any changes, $35.3 \%$ had decreased, $11.9 \%$ had increased, and $11.0 \%$ had quit. Likewise, $51.4 \%$ of alcohol users stated that their habits had not changed, 36.9\% had decreased their alcohol consumption, 6.3\% had increased, and $5.4 \%$ had quit.

Of all the participants, $59.9 \%$ stated that they had received training on COVID-19 disease in the institutions in which they worked. Of these trainees, $80 \%$ were working in a pandemic hospital. A total of 207 (36.1\%) people answered yes to the question: "As far as you know, have you ever had contact with a COVID-19-positive patient?" When asked whether they were tested due to contact with a patient with COVID-19, it was determined that $51(24.6 \%)$ people were tested, and 4 (7.8\%) of 
Table 1. Distribution of radiology workers according to sociodemographic characteristics

\begin{tabular}{l|l}
\hline $\begin{array}{l}\text { Variables } \\
\text { Age (year) }\end{array}$ & N (\%) \\
$\begin{array}{l}\text { Gender } \\
\text { Female }\end{array}$ & $28.0 \pm 9.3$ \\
\hline $\begin{array}{l}\text { Male } \\
\text { Marital status }\end{array}$ & $286(49.9)$ \\
\hline $\begin{array}{l}\text { Married } \\
\text { Single (including widow or divorced) }\end{array}$ & $235(41)$ \\
\hline $\begin{array}{l}\text { Place of residence } \\
\text { City center }\end{array}$ & $338(59)$ \\
\hline $\begin{array}{l}\text { Town } \\
\text { Profession }\end{array}$ & $419(73.1)$ \\
\hline $\begin{array}{l}\text { Radiologist } \\
\text { Radiology technician }\end{array}$ & $154(26.9)$ \\
\hline $\begin{array}{l}\text { Working time (year) } \\
\text { 1-10 }\end{array}$ & $113(19.7)$ \\
\hline $\begin{array}{l}11 \text { and more } \\
\text { Place of work } \\
\text { Pandemic hospital }\end{array}$ & $460(80.3)$ \\
\hline $\begin{array}{l}\text { Other health institutions* } \\
\text { * Integrated hospital, Branch hospital, Cancer early diagnosis and training } \\
\text { center, Tuberculosis dispensary, etc }\end{array}$ & $322(56.2)$ \\
\hline & $251(43.8)$ \\
\hline
\end{tabular}

them were found to be positive.

In answer to the question "What measures do you implement related to COVID-19 in your daily life outside the workplace?" $96.3 \%$ of participants stated that they washed their hands frequently, $84.6 \%$ of them used hand disinfectant/alcohol, $86.4 \%$ of them applied social isolation, and $83.2 \%$ of them ventilated their environment frequently. In answer to the question: "What measures do you implement in your professional life regarding COVID-19?" $98.3 \%$ of them stated that they wore masks, $96.9 \%$ of them washed their hands frequently, $89.7 \%$ of them wore gloves, $78.7 \%$ of them wore aprons, $89.9 \%$ of them used hand disinfectants/alcohol, $78.4 \%$ of them applied social isolation, and $74.2 \%$ of them ventilated their environment frequently. When asked, $27.6 \%$ of the participants stated that the measures taken against COVID-19 in their institution were "sufficient," $54.1 \%$ stated that the measures were "partially sufficient," and $18.3 \%$ stated that they were "insufficient." Of those who stated that the measures taken were sufficient and partially sufficient, $78 \%$ were working in a pandemic hospital.

The scores received by radiology workers from the PSS were 27.8 \pm 6.4 (median: 27.0, minimum-maximum: 6-50). Statistical comparisons were made according to some features of the employees. According to this; it was determined that the perceived stress was statistically significantly higher $(\mathrm{p}<0.05)$ (Table 2) in women and those living with individuals over the age of 60 , those working as radiology technicians, those with a chronic disease, those who increased smoking, those who used social media more often than before, those who had contact with a patient positive for COVID-19, those who did not receive training on COVID-19, and those who thought that the measures taken against COVID-19 were insufficient.

Table 2. Comparison of perceived stress scores of radiology workers according to some variables

\begin{tabular}{|c|c|c|c|c|}
\hline \multirow{2}{*}{$\begin{array}{l}\text { Variables } \\
\text { Mean } \pm \text { SD }\end{array}$} & & \multicolumn{2}{|c|}{$\begin{array}{l}\text { Perceived stress } \\
\text { score }\end{array}$} & \multirow{2}{*}{$\mathrm{P}$} \\
\hline & & \multicolumn{2}{|c|}{$\begin{array}{l}\text { Min-Max } \\
\text { median }\end{array}$} & \\
\hline \multirow{4}{*}{ Gender } & Male & $26.4 \pm 6.0$ & $6-50$ & \multirow{4}{*}{0.000} \\
\hline & & & 21.0 & \\
\hline & Female & $291+65$ & $6-50$ & \\
\hline & मान & $2.0-0.0$ & 29.0 & \\
\hline \multirow{4}{*}{ Marital status } & Married & $277+64$ & $6-50$ & \multirow{4}{*}{0.875} \\
\hline & 然 & & 28.0 & \\
\hline & Single & $279+64$ & $6-50$ & \\
\hline & minge & 21.0-0.7 & 27.0 & \\
\hline \multirow{4}{*}{ Place of residence } & City center & $280+65$ & $6-50$ & \multirow{4}{*}{0.132} \\
\hline & 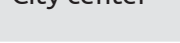 & $20.0-0.0$ & 28.0 & \\
\hline & & $272+62$ & $12-50$ & \\
\hline & (10vi! & $21.2+0.2$ & 27.0 & \\
\hline \multirow{4}{*}{ Children } & Present & $278+64$ & $6-50$ & \multirow{4}{*}{0.910} \\
\hline & 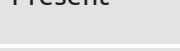 & 21.0 .0 .7 & 28.0 & \\
\hline & Absent & $27.8+6.4$ & $6-50$ & \\
\hline & Ruseill & $21.0 \pm 0.4$ & 27.0 & \\
\hline \multirow{4}{*}{$\begin{array}{l}>60 \text { elderly } \\
\text { individuals living } \\
\text { together }\end{array}$} & Present & $298+61$ & $15-50$ & \multirow{4}{*}{0.005} \\
\hline & (1) & $20.0-0.1$ & 28.0 & \\
\hline & Absent & $274+641$ & $6-50$ & \\
\hline & Auseil & $21.4 \pm 0.41$ & 27.0 & \\
\hline \multirow{4}{*}{ Profession } & Radiologist & $26.4 \pm 6.2$ & $6-44$ & \multirow{4}{*}{0.007} \\
\hline & & & 26.0 & \\
\hline & Radiology & $281+64$ & $6-50$ & \\
\hline & technician & 20.110 .4 & 28.0 & \\
\hline \multirow{4}{*}{ Working time (year) } & $1-10$ & $27.4 \pm 6.2$ & $12-44$ & \multirow{4}{*}{0.825} \\
\hline & & & 27.0 & \\
\hline & 11 and over & $282+67$ & $6-50$ & \\
\hline & I I d and over & $\angle 8 . \angle \pm 6.1$ & 28.0 & \\
\hline \multirow{4}{*}{ Place of work } & Pandemic & $27.7 \pm 6.3$ & $6-50$ & \multirow{4}{*}{0.399} \\
\hline & hospital & & 27.0 & \\
\hline & Other health & $287+67$ & $6-50$ & \\
\hline & institutions & $20.2+0.1$ & 28.0 & \\
\hline \multirow{4}{*}{ Chronic illness } & Present & $289+67$ & $6-44$ & \multirow{4}{*}{0.010} \\
\hline & (1) & $20.0-0.1$ & 29.0 & \\
\hline & thcent & $270+60$ & $6-50$ & \\
\hline & ADsent & $21.0 \pm 0.0$ & 27.0 & \\
\hline
\end{tabular}




\begin{tabular}{|c|c|c|c|c|}
\hline \multirow{5}{*}{$\begin{array}{l}\text { Cigarette } \\
\text { consumption }\end{array}$} & Never smoked & $27.8 \pm 6.4$ & $\begin{array}{l}6-50 \\
27.0\end{array}$ & \multirow{5}{*}{0.009} \\
\hline & $\begin{array}{l}\text { Did not } \\
\text { change }\end{array}$ & $26.3 \pm 6.5$ & $\begin{array}{l}6-43 \\
27.0\end{array}$ & \\
\hline & Increased & $31.7 \pm 7.1$ & $\begin{array}{l}20-50 \\
32.0\end{array}$ & \\
\hline & Decreased & $28.3 \pm 5.9$ & $\begin{array}{l}11-41 \\
29.0\end{array}$ & \\
\hline & Quitted & $27.6 \pm 5.3$ & $\begin{array}{l}16-39 \\
28.0\end{array}$ & \\
\hline \multirow{5}{*}{$\begin{array}{l}\text { Alcohol } \\
\text { consumption }\end{array}$} & Never used & $27.8 \pm 6.4$ & $\begin{array}{l}6-50 \\
27.0\end{array}$ & \multirow{5}{*}{0.945} \\
\hline & $\begin{array}{l}\text { Did not } \\
\text { change }\end{array}$ & $27.5 \pm 7.4$ & $\begin{array}{l}6-50 \\
27.0\end{array}$ & \\
\hline & Increased & $28.2 \pm 4.3$ & $\begin{array}{l}21-34 \\
29.0\end{array}$ & \\
\hline & Decreased & $28.4 \pm 5.8$ & $\begin{array}{l}12-41 \\
28.0\end{array}$ & \\
\hline & Quitted & $27.6 \pm 2.0$ & $\begin{array}{l}24-30 \\
28.0\end{array}$ & \\
\hline \multirow{3}{*}{ Social media usage } & Increased & $28.7 \pm 6.1$ & $\begin{array}{l}12-50 \\
28\end{array}$ & \multirow{3}{*}{0.026} \\
\hline & Decreased & $26.7 \pm 8.5$ & $\begin{array}{l}12-43 \\
27\end{array}$ & \\
\hline & $\begin{array}{l}\text { Did not } \\
\text { change }\end{array}$ & $27.2 \pm 6.3$ & $\begin{array}{l}6-50 \\
27.0\end{array}$ & \\
\hline \multirow{2}{*}{ COVID-19 training } & Present & $27.4 \pm 6.6$ & $\begin{array}{l}6-50 \\
27.0\end{array}$ & \multirow{2}{*}{0.045} \\
\hline & Absent & $28.4 \pm 6.1$ & $\begin{array}{l}6-44 \\
28.0\end{array}$ & \\
\hline \multirow{2}{*}{$\begin{array}{l}\text { Contact with a } \\
\text { patient positive for } \\
\text { COVID-19 }\end{array}$} & Present & $28.5 \pm 6.9$ & $\begin{array}{l}6-50 \\
28.0\end{array}$ & \multirow{2}{*}{0.020} \\
\hline & Absent & $27.4 \pm 6.0$ & $\begin{array}{l}6-50 \\
27.0\end{array}$ & \\
\hline \multirow{3}{*}{$\begin{array}{l}\text { Measures taken } \\
\text { against COVID-19 }\end{array}$} & Sufficient & $26.1 \pm 6.0$ & $\begin{array}{l}12-42 \\
26.0\end{array}$ & \multirow{3}{*}{0.000} \\
\hline & $\begin{array}{l}\text { Partially } \\
\text { sufficient }\end{array}$ & $28.0 \pm 6.5$ & $\begin{array}{l}6-50 \\
28.0\end{array}$ & \\
\hline & Insufficient & $29.8 \pm 6.2$ & $\begin{array}{l}13-44 \\
29.0\end{array}$ & \\
\hline
\end{tabular}

SD: Standard deviation, Min: Minimum, Max: Maximum, COVID-19: Coronavirus disease-19

\section{Discussion}

COVID-19 is an atypical pneumonia pandemic that has caused the most cases and deaths in the world after the SARS outbreak in $2003(18,19)$. As the infection may be asymptomatic, with the progression of atypical pneumonia, approximately $2 \%$ of cases are lost due to acute respiratory distress syndrome $(20,21)$. Clinical and radiological findings and diagnostic tests are used for the diagnosis of the disease. The role of thorax CT for the diagnosis and follow-up in individuals infected with COVID-19 has led radiology clinics to take an active place in the field (2223).

People complied with social isolation and, to avoid becoming infected, did not leave their homes. However, healthcare workers, who assumed the most important task in the outbreak, were unable to cut off contact with the outside and with patients. Close contact and a high-risk of transmission threaten the mental and physical health of healthcare workers. During the SARS outbreak in $2003,89 \%$ of healthcare workers in high-risk situations were reported to develop psychological symptoms $(24,25)$.

Although the best approach to struggling with outbreaks is still uncertain, maintaining the mental health of healthcare workers is a requirement for better control of infectious diseases $(26,27)$. Most research on the COVID-19 outbreak has focused on virus characterization, disease progression, and outbreak management $(20,21,28)$. Sterilization of the radiology department, methods of personnel protection and the provision of an optimal safe working environment have been addressed in many scientific articles $(29,30)$. However, there is no study in the literature about the psychological effects of this pandemic on radiology staff. This study provides an overview of the evaluation of the stress levels perceived by radiology workers during the COVID-19 pandemic. At the same time, it is the first study to assess the psychological status of employees working in radiology units during the COVID-19 outbreak in Turkey.

Compared with other outbreaks, the high transmission rate of COVID-19, in addition to the prevalence of asymptomatic patients, makes it difficult to control the outbreak $(3,31)$. The most commonly used imaging method in diagnosis is thorax CT. Tomography rooms are closed areas, so radiology workers often have to be in close contact with the patient during tomography and positioning. Because of this, they cannot maintain their social isolation distance. In addition, it may be necessary to evaluate COVID-19 patients with other imaging methods and perform interventions during their follow-up in the hospital (32). In our study, $36.1 \%$ of the participants had a direct contact history with COVID-19-positive patients. The perceived stress level was found to be higher in those working in the pandemic hospital and in the group who came into contact with patients. We believe that this is due to the fact that radiology workers experience significant stress about becoming ill and transmitting the disease. In the study by Wang et al. (33), it was reported that more than $70 \%$ of the participants believed that they would recover after becoming infected, but they were concerned about their family members because they could not discontinue contact with them. In addition, epidemiological studies have shown that the disease progresses with higher mortality and morbidity rates in the elderly and the infection is associated with higher mortality in individuals with chronic disease $(20,21,34)$. In our study, PSS 
scores were higher in both those living with individuals over the age of 60 and those with a chronic disease. It can be interpreted that these people were concerned not only for their own health but also for that of their relatives.

Our sociodemographic data showed that the perceived stress level was higher in those of the female gender, those who were married and parents. This finding is parallel with previous epidemiological studies that found women to be at higher risk for depression $(33,35)$. This situation may be attributed to female healthcare workers' concerns about becoming ill and carrying the virus to their families and children. Moreover, it can be related to their concerns about the disruption of family lifestyle or the care of their children if they are isolated/quarantined due to their own infection.

In our study, it was determined that $59.9 \%$ of the participants received training about COVID-19 disease in the institution where they work and the perceived stress level in the educated group was lower than those who were not trained. Similarly, the perceived stress level of radiologists was lower. Although the contents of these trainings are not known exactly, it can be assumed that the course of the disease, its clinical features, and the means of prevention are described. We believe that physicians, who have greater knowledge about diseases and means of prevention, and radiology workers who have gained knowledge through the training they have received, act more consciously during the hours they spend in the hospital and feel more secure. In an article emphasizing the personal protection problems of healthcare workers in China, it was reported that infection rates increased during the pandemic because healthcare workers did not have enough time for systematic training and practices (36). During the course of the pandemic, the diagnosis, treatment strategies, and protection recommendations of the healthcare workers have changed in the light of new data and the guidelines of health authorities have been revised. In previous studies, it has been reported that health authorities providing accurate and sufficient information in the outbreak are associated with lower stress, anxiety, and depression levels during the outbreak $(33,37)$.

Social media pollution is an important cause of stress during outbreaks. It is known that the increasing number of new cases and deaths day by day, disinformation and false reports increase anxiety. During the COVID-19 outbreak, in their study of Chinese citizens over the age of 18, Gao et al. (38) reported that $82 \%$ of participants were exposed to social media a lot and had symptoms of high anxiety and depression. In our study, it was observed that the perceived stress was higher in the group using social media intensively. We believe that information pollution in social media negatively affects radiology workers in our country as well as all over the world.

It is important to limit transmission from person to person in order to reduce secondary infections among healthcare workers. Personal protective equipment is an important component that protects personnel from COVID-19, and correct use significantly reduces the risk of viral contamination $(39,40)$. It has been reported by the China National Hospital Infection Management and Quality Control Center that the awareness of healthcare professionals about personal protection was inadequate due to the lack of recognition of the pathogen at the onset of the COVID-19 outbreak. As China was caught unprepared for the pandemic, long-term exposure to many patients and a lack of personal protective equipment increased the risk of infection in healthcare workers (36). During the 2003 SARS-CoV epidemic, researchers found that moderate anxiety levels were associated with participants taking more preventive measures. Regardless of the presence or absence of symptoms, special measures such as avoiding sharing items, hand hygiene and wearing a mask were associated with lower levels of depression, anxiety, and stress (33). In our study, radiology workers stated that they applied infection control measures both in their private lives and in the hospital. Despite contact with large numbers of patients, we think that the infection of only four radiology workers with COVID-19 was a result of correct and sufficient implementation of prevention methods. In addition, it was observed that most of the participants in the study were those working in hospitals designated as pandemic hospitals, and the scale scores of these people were similar to those of participants working in other health institutions. Although there is a higher risk of contact with COVID-positive patients, the lack of a high perception of stress can be attributed to the amount of protective equipment in these hospitals being more adequate than in other institutions or to the training provided to the personnel.

\section{Study Limitations}

This study has some limitations. In our study, the optional webbased survey method was used, because of this, the possibility of selection bias cannot be ignored. In addition, we tried to determine the participants' psychiatric conditions before the pandemic with only one question, but clinical evaluation could not be performed.

\section{Conclusion}

As a result, there are some risk groups among radiology workers who are known to have an increased risk of infection due to contact with patients as well as an increased workload due to the COVID-19 outbreak. These can perceive higher levels of stressors, resulting in deterioration of their mental health. These include some personal characteristics such as female gender, smoking, presence of chronic disease, or living with older individuals, as well as some professional characteristics such as occupational group, contact with COVID-19-positive patients, education and lack of personal protection. We think that early detection and intervention of those with high stress perception is important to reduce the psychological complaints of employees and to protect their mental health. It will also contribute to the reduction of workforce losses and the prevention of other staff's workload increases due to sick leave/medical reports in the current period of struggle with pandemics. However, more comprehensive studies are needed for effective interventions for high-risk groups. 


\section{Ethics}

Ethics Committee Approval: OMU-CREC 2020/170.

Peer-review: Externally peer reviewed.

\section{Authorship Contributions}

Concept: H.N.A., A.İ.S., Design: H.N.A., A.İ.S., Data Collection or Processing: H.N.A., A.İ.S., Analysis or Interpretation: H.N.A., A.İ.S., Literature Search: H.N.A., A.İ.S., Writing: H.N.A., A.İ.S.

Conflict of Interest: No conflict of interest was declared by the authors.

Financial Disclosure: This work was supported by Gilead Sciences.

\section{References}

1. Lu H, Stratton CW, Tang YW. Outbreak of pneumonia of unknown etiology in Wuhan, China: The mystery and the miracle. J Med Virol 2020;92:401-2.

2. World Health Organization. WHO Director-General's Remarks at the Media Briefing on 2019-nCoV on 11 February 2020. Available from: https://www.who.int/dg/speeches/detail/who-directorgeneral-s-remarks-at-the-media-briefing-on-2019-ncov-on-11february-2020.

3. Li Q, Guan X, Wu P, Wang X, Zhou L, Tong Y, et al. Early transmission dynamics in Wuhan, China, of novel coronavirusinfected pneumonia. N Engl J Med 2020 Mar;382:1199-207.

4. World Health Organization. Report of the WHO-China Joint Mission on Coronavirus Disease 2019 (COVID-19). Available from: https://www.who.int/docs/default-source/coronaviruse/who-chinajoint-mission-on-covid-19-final-report.pdf.

5. Del Rio C, Malani PN. COVID-19-new insights on a rapidly changing epidemic. JAMA 2020;323:1339-40.

6. Fang Y, Zhang H, Xie J, Lin M, Ying L, Pang P, et al. Sensitivity of chest CT for COVID-19: Comparison to RT-PCR. Radiology 2020;296:115-7.

7. Lei P, Huang Z, Liu G, Wang P, Song W, Mao J, et al. Clinical and computed tomographic (CT) images characteristics in the patients with COVID-19 infection: What should radiologists need to know? J Xray Sci Technol 2020;28:369-81.

8. Yu J, Ding N, Chen H, Liu XJ, He WJ, Dai WC, et al. Infection control against COVID-19 in departments of radiology. Acad Radiol 2020;27:614-7.

9. Wu KK, Chan SK, Ma TM. Posttraumatic stress, anxiety, and depression in survivors of severe acute respiratory syndrome (SARS). J Trauma Stress 2005;18:39-42.

10. Wu KK, Chan SK, Ma TM. Posttraumatic stress after SARS. Emerg Infect Dis 2005;11:1297-300.

11. Maunder R, Hunter J, Vincent L, Bennett J, Peladeau N, Leszcz M, et al. The immediate psychological and occupational impact of the 2003 SARS outbreak in a teaching hospital. CMAJ 2003;168:1245-51.

12. Lung FW, Lu YC, Chang YY, Shu BC. Mental symptoms in different health professionals during the SARS attack: A follow-up study. Psychiatr Q 2009;80:107-16.
13. Robertson E, Hershenfield K, Grace SL, Stewart DE. The psychosocial effects of being quarantined following exposure to SARS: a qualitative study of Toronto health care workers. Can J Psychiatry 2004;49:403-7.

14. Lai J, Ma S, Wang Y, Cai Z, Hu J, Wei N, et al. Factors associated with mental health outcomes among health care workers exposed to coronavirus disease 2019. JAMA Netw Open 2020;3:203976.

15. Lu W, Wang H, Lin Y, Li L. Psychological status of medical workforce during the COVID-19 pandemic: A cross-sectional study. Psychiatry Res 2020;288:112936.

16. Cohen S, Kamarck T, Mermelstein R. A global measure of perceived stress. J Health Soc Behav 1983;24:385-96.

17. Eskin M, Harlak H, Demirkıran F, Dereboy Ç. The Adaptation of the perceived stress scale into Turkish: A reliability and validity analysis. Yeni Symposium 2013;51:132-40.

18. Wang C, Horby PW, Hayden FG, Gao GF. A novel coronavirus outbreak of global health concern. Lancet 2020;395:470-3.

19. Nishiura H, Jung SM, Linton NM, Kinoshita R, Yang Y, Hayashi $\mathrm{K}$, et al. The extent of transmission of novel coronavirus in Wuhan, China, 2020. J Clin Med 2020;9:330.

20. Huang C, Wang Y, Li X, Ren L, Zhao J, Hu Y, et al. Clinical features of patients infected with 2019 novel coronavirus in Wuhan, China. Lancet 2020;395:497-506.

21. Chen N, Zhou M, Dong X, Qu J, Gong F, Han Y, et al. Epidemiological and clinical characteristics of 99 cases of 2019 novel coronavirus pneumonia in Wuhan, China: a descriptive study. Lancet 2020;395:507-13.

22. Yang W, Sirajuddin A, Zhang X, Liu G, Teng Z, Zhao S, et al. The role of imaging in 2019 novel coronavirus pneumonia (COVID-19). Eur Radiol 2020;30:4874-82.

23. Liang T, Liu Z, Wu CC, Jin C, Zhao H, Wang Y, et al. Evolution of CT findings in patients with mild COVID-19 pneumonia. Eur Radiol 2020;30:4865-73.

24. Lee AM, Wong JG, McAlonan GM, Cheung V, Cheung C, Sham PC, et al. Stress and psychological distress among SARS survivors 1 year after the outbreak. Can J Psychiatry 2007;52:233-40.

25. Chua SE, Cheung V, Cheung C, McAlonan GM, Wong JW, Cheung EP, et al. Psychological effects of the SARS outbreak in Hong Kong on high-risk health care workers. Can J Psychiatry 2004;49:391-3.

26. Zhang WR, Wang K, Yin L, Zhao WF, Xue Q, Peng M, et al. Mental health and psychosocial problems of medical health workers during the COVID-19 epidemic in China. Psychother Psychosom 2020;89:242-50.

27. Xiang YT, Yang Y, Li W, Zhang L, Zhang Q, Cheung T, et al. Timely mental health care for the 2019 novel coronavirus outbreak is urgently needed. Lancet Psychiatry 2020;7:228-9.

28. Lu R, ZhaoX, Li J, Niu P, Yang B, Wu H, et al. Genomic characterisation and epidemiology of 2019 novel coronavirus: implications for virus origins and receptor binding. Lancet 2020;395:565-74.

29. Zhao D, Zhang C, Chen J Dr. Infection control in the medical imaging department during the COVID-19 pandemic. J Med Imaging Radiat Sci 2020;51:204-6. 
30. Orsi MA, Oliva G, Toluian T, Valenti Pittino C, Gibelli D, Cellina M. Comment on "COVID-19 infection control protocol inside computed tomography suites”. Jpn J Radiol 2020;38:693-4.

31. Rothe C, Schunk M, Sothmann P, Bretzel G, Froeschl G, Wallrauch C, et al. Transmission of 2019-nCoV infection from an asymptomatic contact in Germany. N Engl J Med 2020;382:970-1.

32. Lomoro P, Verde F, Zerboni F, Simonetti I, Borghi C, Fachinetti C, et al. COVID-19 pneumonia manifestations at the admission on chest ultrasound, radiographs, and CT: single-center study and comprehensive radiologic literature review. Eur J Radiol Open 2020;7:100231.

33. Wang C, Pan R, Wan X, Tan Y, Xu L, Ho CS, et al. Immediate psychological responses and associated factors during the initial stage of the 2019 coronavirus disease (COVID-19) epidemic among the general population in China. Int J Environ Res Public Health 2020;17:1729.

34. Liu K, Chen Y, Lin R, Han K. Clinical features of COVID-19 in elderly patients: A comparison with young and middle-aged patients. J Infect 2020;80:14-18.
35. Sprang G, Silman M. Posttraumatic stress disorder in parents and youth after health-related disasters. Disaster Med Public Health Prep 2013;7:105-10.

36. Wang J, Zhou M, Liu F. Reasons for healthcare workers becoming infected with novel coronavirus disease 2019 (COVID-19) in China. J Hosp Infect 2020;105:100-1.

37. Rubin GJ, Wessely S. The psychological effects of quarantining a city. BMJ 2020;368:313.

38. Gao J, Zheng P, Jia Y, Chen H, Mao Y, Chen S, et al. Mental health problems and social media exposure during COVID-19 outbreak. PLoS One 2020;15:0231924

39. Cook TM. Personal protective equipment during the coronavirus disease (COVID) 2019 pandemic - a narrative review. Anaesthesia 2020;75:920-7.

40. World Health Organization. Novel coronavirus (2019-nCoV). Situation report. Available from: https://www.who.int/docs/defaultsource/coronaviruse/situation-reports/20200208-sitrep-19-ncov. pdf?sfvrsn=6e091ce6_4. 